\title{
Video Animasi Matematika Dasar Menggunakan Metode Jarimatika (Studi Kasus: TK YWKA II Purwokerto)
}

\author{
Animation Video of Basic Mathematics Using the Jarimatika Method \\ (Case Study: TK YWKA II Purwokerto)
}

\author{
Yuli Purwati*1, Tandi Kukuh Jati Laksono ${ }^{2}$, Suliswaningsih ${ }^{3}$, Dwi Krisbiantoro \\ 1,2,3,4 Informatika; Universitas Amikom Purwokerto \\ ${ }_{1,2,3,4}$ Purwokerto, Indonesia \\ e-mail: *1yulipurwati@ amikompurwokerto.ac.id, ${ }^{2}$ tandikukuh1@ gmail.com, \\ ${ }^{3}$ suliswani@amikompurwokerto.ac.id, ${ }^{4}$ dwikris@ amikompurwokerto.ac.id
}

\begin{abstract}
Abstrak - Pendidikan merupakan suatu proses yang penting dalam perkembangan suatu individu ataupun sebuah kelompok sosial masyarakat, pendidikan sendiri dimulai sejak usia dini. Salah satu bentuk pendidikan anak usia dini yaitu taman kanak-kanak. Salah satu lingkup perkembangan yang harus dicapai pada tingkat pencapaian perkembangan anak usia dini adalah kemampuan kognitif yang terdiri dari pengetahuan umum dan sains, konsep bentuk, warna, ukuran dan pola, konsep bilangan, lambang bilangan dan menghitung. Oleh sebab itu, kemampuan dasar matematika perlu dirangsang dan dikembangkan sejak dini. Tujuan dari penelitian ini yaitu untuk mengajarkan dan menarik antusias anak didik di TK YWKA II dalam belajar berhitung matematika menggunakan media video animasi 2D. Video animasi dibuat dengan menggunakan teknik papper cut dan motion graphic. Metode pengumpulan data pada penelitian ini berupa wawancara, observasi dan studi pustaka. Pada penelitian ini dihasilkan video animasi belajar matematika tentang penjumlahan dan pengurangan menggunakan metode jarimatika yang diadaptasi dari ebook karya Septi Peni Wulandani dengan durasi tujuh menit tiga puluh detik kemudian dilanjutkan dengan pengujian alpha yang menunjukan bahwa hasil uji tersebut sudah sesuai antara storyboard dengan hasil akhir. Hasil yang diperoleh dari uji validasi ahli materi dengan nilai 4,28 dan ahli media dengan nilai 4,29 termasuk kategori layak. Uji kelayakan faktor usability memperoleh nilai 5,36 dan dikategorikan layak sebagai media pembelajaran matematika dasar.
\end{abstract}

Kata kunci: Jarimatika; Matematika; Motion Graphic; Papper Cut; Video Animasi;

\begin{abstract}
Education is a process of development of community groups or community groups, education starts early. The form of education is in the form of kindergarten (TK) like TK YWKA II in Purwokerto. The purpose of this study is to study and attract students in YWKA II Kindergarten in learning to count mathematics using 2-dimensional animated video media. Limitations of the problem in research involving techniques that only use papper cut, motion graphics, and discuss how to learn fingerprints starting with the method of hoping data in this study consisted of interviews, observation and literature study. In this research, an animation video about mathematics learning about addition and usage is produced using the Jarimatika method with a duration of seven minutes and thirty seconds, then continued with alpha testing which shows the results of the research in accordance with the storyboard with the final results. The results obtained from the material expert validation test with a value of 4.28 and media experts with a value of 4.29 are categorized as feasible. The usability factor feasibility test obtained a value of 5.36 and was categorized as feasible as a medium for learning basic mathematics.
\end{abstract}

Keywords: Jarimatika; Mathematics; Motion Graphic; Papper Cut; Video Animation; 


\section{PENDAHULUAN}

Pendidikan merupakan suatu proses yang penting dalam perkembangan suatu individu ataupun sebuah kelompok sosial masyarakat. Pendidikan yang sudah diperoleh juga menjadi salah satu tolak ukur untuk melihat kemajuan suatu masyarakat. Dalam hal ini sekolah sendiri merupakan lembaga yang bertugas sebagai tempat untuk mendidik, membimbing, dan membentuk karakter dari para peserta didik.

Pendidikan anak usia dini adalah pendidikan untuk membantu pertumbuhan dan perkembangan anak usia dini sesuai dengan karakteristik anak, sehingga anak dapat menjadi generasi penerus bagi bangsa Indonesia. Salah satu bentuk pendidikan anak usia dini yaitu taman kanak-kanak. TK merupakan lembaga yang memberikan layanan pendidikan bagi anak usia dini pada rentang usia 4-6 tahun [1]. Salah satu lingkup perkembangan yang harus dicapai pada tingkat pencapaian perkembangan anak usia 5-6 tahun adalah kemampuan kognitif yang terdiri dari pengetahuan umum dan sains, konsep bentuk, warna, ukuran dan pola, konsep bilangan dan lambang bilangan. Kemampuan ini dapat dilihat dari kemampuan anak dalam mengenal konsep bilangan, menghitung. Oleh sebab itu, kemampuan dasar matematika perlu dirangsang dan dikembangkan sejak dini [2].

Berhitung merupakan dasar dari beberapa ilmu yang dipakai dalam setiap kehidupan manusia. Mengingat begitu pentingnya kemampuan berhitung bagi manusia, maka kemampuan berhitung ini perlu diajarkan sejak dini, dengan berbagai media dan metode yang tepat [3]. Matematika sendiri adalah mata pelajaran yang penting. Matematika juga termasuk mata pelajaran yang menjadi standar untuk diujikan ketika akan melanjutkan ke jenjang pendidikan yang lebih tinggi [4]. Berhitung dilakukan dengan berbagai macam kegiatan dengan menggunakan media yang lebih menarik sehingga dapat mempengaruhi minat belajar dalam berhitung. Karena dengan penggunaan media pada proses pembelajaran membuat anak akan mudah tertarik. Pengertian media sendiri merupakan salah satu penyalur informasi atau penyampaian pesan sebagai alat pembelajaran [5].

Seperti hasil wawancara penulis dengan Ibu Sri Kustanti selaku guru di TK Yayasan Wanita Kereta Api II Purwokerto ini mengatakan, pembelajaran berhitung di mulai dari hal yang paling dasar, seperti dari pengenalan seperti dari pengenalan berhitung dan dilanjutkan dengan pengenalan lambang bilangan terlebih dahulu Kemudian cara mengajarnya yaitu sambil bermain melalui konsep lambang bilangan, selanjutnya dengan cara menghitung manik-manik, benda-benda dari wadah satu ke wadah yang lain, atau bisa juga dengan cara bercerita dan bernyanyi. Tidak adanya ketersediaan sumber media sehingga hanya metode tersebut saja yang di pakai dalam mengajar sehingga antusias anak-anak juga dianggap kurang.

Jarimatika merupakan salah satu metode berhitung (operasi Kali-Bagi-Tambah-Kurang) dengan menggunakan jari-jari tangan, metode ini banyak dikembangkan di Indonesia salah satunya oleh Septi Peni Wulandari pada tahun 2004. Metode jarimatika ini memiliki kelebihan di bandingkan dengan metode lain, jarimatika lebih menekankan pada penguasaan konsep terlebih dahulu baru ke cara cepatnya sehingga anak-anak menguasai ilmu secara matang. Penelitian animasi matematika atau jarimatika sebelumnya: Wahyu Tisno Atmojo, dkk. (2019) [6], membuat kuis dan puzzle pelajaran matematika untuk alat belajar menghitung. Bernadhed, dkk. (2019) [7], mengembangkan media belajar jarimatika menggunakan animasi namun baru sebatas rancangan dan belum diimplementasikan. Ali Subhan Afrizal (2018) [8], membuat aplikasi pembelajaran jarimatika interaktif menggunakan flash untuk perkalian 69 di sekolah dasar. Arbella Sri Marleny M, dkk. (2016)[9], menerapkan metode jarimatika berbantuan Adobe Animate untuk mengamati tingkat motivasi belajar siswa di kelas.

Berdasarkan uraian tersebut tujuan penelitian ini adalah membuat media belajar matematika dasar dengan metode jarimatika menggunakan video animasi 2 Dimensi. Penelitian ini menerapkan teknik paper cut out yang dikombinasikan dengan motion graphic dalam pembuatan animasi. Kedua teknik tersebut dipilih karena penerapan motion pada animasi lebih fleksibel, dimana seluruh aset motion graphics dibuat dari nol sehingga, motion graphics atau gerakan pada karakter dapat diubah dan disesuaikan dengan kebutuhan. Kemudian paper cut out juga diterapkan karena dapat menghemat waktu dalam proses produksi sekaligus menghemat biaya produksi. Dengan dibuatnya media pembelajaran tersebut diharapkan nantinya dapat menarik minat dan meningkatkan antusias anak-anak di TK YWKA II Purwokerto dalam belajar berhitung 
matematika.

\section{LANDASAN TEORI}

\section{Animasi}

Animasi adalah presentasi statis yang menjadi hidup. Animasi adalah teknik memotret gambar atau posisi suatu objek untuk menciptakan ilusi gerakan secara terus-menerus. Animasi merupakan objek yang bergerak melintasi atau bergerak ke dalam dan keluar pada tampilan layer. Animasi memiliki beberapa jenis yaitu animasi 2dimensi dan animasi 3dimensi [10].

\section{Jarimatika}

Metode berhitung dengan memanfaatkan jari-jari tangan untuk alat bantu menyelesaikan Aritmatika: Kali -Bagi-Tambah - dan Kurang atau KaBaTaku. Kelebihan metode jarimatika adalah adanya visualisasi proses berhitung dan relatif tidak memberatkan otak serta lebih menarik minat anak dengan menggerakan jarijari tangan [11].

\section{Teknik paper cut out}

Teknik cut out adalah salah satu teknik tertua dan sederhana yang mempunyai banyak bentuk serta variasi. Cut out dapat dilihat juga sebagai animasi puppet $2 \mathrm{D}$. Ciri khas cut out biasanya terbuat dari kertas, karton maupun kain yang digabungkan dengan string atau pengencang kertas kecil sehingga kertas tersebut dapat dipindah frame by frame [12].

\section{Teknik Motion graphic}

Motion graphic adalah istilah yang digunakan untuk menggambarkan berbagai solusi desain grafis professional dalam menciptakan suatu desain komunikasi yang dinamis dan efektif untuk film, televisi dan internet. Oleh karena itu diperlukan strategi, kreativitas, dan keterampilan dari seorang desainer broadcasting, desainer judul film dan animator dalam seni motion graphic [13].

\section{METODE}

\section{Metode Pengumpulan Data}

Adapun metode-metode pengumpulan data yang digunakan pada penelitian ini yaitu berupa observasi, wawancara dan studi pustaka:

\section{Observasi}

Dalam penelitian ini, observasi dilakukan dengan mendatangi langsung TK YWKA II Purwokerto yang menjadi tempat penelitian penulis guna melihat langsung aktivitas belajar siswa di TK YWKA sekaligus untuk mendapatkan informasi lainnya yang masih berhubungan dengan penelitian.

\section{Wawancara}

Wawancara dilakukan dengan menemui narasumber secara langsung yaitu Ibu Sri Kustanti selaku guru di TK Yayasan Wanita Kereta Api (YWKA) II guna mendapatkan informasi yang penulis butuhkan dengan memberikan beberapa pertanyaan-pertanyaan yang berhubungan dengan penelitian.

\section{Studi Pustaka}

Dalam studi pustaka ini penulis mengumpulkan data-data yang dilakukan dengan mempelajari buku-buku, jurnal maupun sumber lainnya seperti di internet yang ada kaitannya dengan penelitian.

\section{Metode Pengembangan}

Metode pengembangan untuk memproduksi sistem multimedia melibatkan tiga tahapan, yaitu pra-produksi, produksi dan pasca produksi [10].

\section{Pra-produksi}

Tahap pra-produksi adalah tahap semua pekerjaan dan aktivitas yang terjadi sebelum multimedia komersial diproduksi secara nyata. Perencanaan secara baik sebelum diproduksi dapat menghemat biaya bagi pemesan multimedia komersial. Pada tahapan ini dilakukan beberapa proses yaitu: menentukan tema, dan membuat storyboard.

\section{Produksi}

Tahap produksi adalah periode selama multimedia di produksi secara komersial. Pada tahap ini syuting dilakukan, suara direkam, pencahayaan diatur, dan kamera dipilih. Pada tahap produksi ini merupakan tahap dimana proses pembuatan video dimulai diantaranya: design property dan asset, editing, dubbing dan music sound effect.

\section{Post produksi}

Tahap pasca produksi adalah periode semua pekerjaan di aktivitas yang telah terjadi setelah multimedia diproduksi secara nyata untuk tujuan komersial. Pasca produksi tersebut meliputi, pengeditan, pemberian efek-efek special, perekaman efek suara, penampuran audio dan video, persetujuan pemesan atau agensi, penggandaan dan penyerahan atau penyiaran (untuk iklan TV). Tahapan ini adalah tahap terakhir pada proses multimedia yang sudah dilakukan sebelumnya yaitu: penggabungan video dan music, rendering, pengujian dan distribusi. 
Tahap pengujian pada penelitian ini adalah dengan melakukan uji coba pada video animasi matematika dasar dengan metode jarimatika dengan membagikan angket kuisioner untuk mengetahui kelayakan produk yang telah dihasilkan untuk kemudian dilakukan evaluasi.

Tahap evaluasi bertujuan untuk mengetahui apakah video yang dibuat sudah sesuai dengan yang diharapkan oleh pengguna [14]. Tahap uji validasi ahli pada aspek media dan materi dilakukan untuk melihat kesesuaian antara video animasi dengan materi yang harus diterima siswa. Uji materi terdiri dari kualitas dan kelayakan media pembelajaran meliputi aspek relevansi materi, aspek pengorganisasian materi, aspek evaluasi, bahasa, tampilan visual dan aspek strategi pembelajaran [15][16]. Uji validasi ini terbagi menjadi dua yaitu untuk ahli media seperti pada Tabel 1, dan ahli materi Tabel 2.

Tabel 1. Kisi-kisi Instrumen Ahli Media

\begin{tabular}{clcc}
\hline \multicolumn{1}{c}{ Aspek } & \multicolumn{1}{c}{ Indikator } & Butir & Soal \\
\hline $\begin{array}{c}\text { Komunikasi } \\
\text { Visual }\end{array}$ & Komunikatif & 2 & 1,2 \\
& $\begin{array}{l}\text { Kreatif dalam gagasan } \\
\text { dan ide }\end{array}$ & 2 & 3,4 \\
& $\begin{array}{l}\text { Tampilan sederhana } \\
\text { dan menarik }\end{array}$ & 2 & 5,6 \\
& $\begin{array}{l}\text { Penggunaan visual } \\
\text { Pemilihan warna }\end{array}$ & 2 & 7,8 \\
& $\begin{array}{l}\text { Pemilihan jenis huruf } \\
\text { Kualitas visual dan }\end{array}$ & 2 & 11,12 \\
& audio & 13,14 \\
\hline
\end{tabular}

Tabel 2. Kisi-kisi Instrumen Ahli Materi

\begin{tabular}{llcc}
\hline \multicolumn{1}{c}{ Aspek } & \multicolumn{1}{c}{ Indikator } & Butir & Soal \\
\hline $\begin{array}{l}\text { Kebenaran } \\
\text { Konsep }\end{array}$ & $\begin{array}{l}\text { Kejelasan tujuan } \\
\text { pembelajaran }\end{array}$ & 2 & 1,2 \\
& $\begin{array}{l}\text { Kebenaran materi } \\
\text { ditinjau dari aspek } \\
\text { keilmuan }\end{array}$ & 2 & 3,4 \\
& Penggunaan bahasa & 2 & 5,6 \\
$\begin{array}{l}\text { Penyusunan } \\
\text { Materi }\end{array}$ & Kesusaian materi & 2 & 7,8 \\
& Kedalaman materi & 2 & 9,10 \\
& & &
\end{tabular}

\begin{tabular}{lcc} 
Kontektualitas & 2 & 11,12 \\
$\begin{array}{l}\text { Kelengkapan bahan } \\
\text { pendukung materi }\end{array}$ & 2 & 13,14 \\
$\begin{array}{l}\text { Kemudahan materi } \\
\text { untuk dipahami }\end{array}$ & 2 & 15,16 \\
$\begin{array}{l}\text { Alur logika yang } \\
\text { jelas }\end{array}$ & 2 & 17,18 \\
\hline
\end{tabular}

Subjek penelitian ini adalah satu ahli media dan satu ahli materi, serta melibatkan 20 siswa pada di TK YWKA II Purwokerto. Sedangkan objek yaitu Video Animasi Matematika Dasar Menggunakan Metode Jarimatika.

Skor yang telah diperoleh kemudian dikonversi menjadi nilai dengan rumus skala dengan rentang nilai seperti seperti dinyatakan dalam Tabel 3[14] :

Tabel 3. Konversi Skala Skor Menjadi Nilai

\begin{tabular}{ll}
\hline \multicolumn{1}{c}{ Kriteria } & \multicolumn{1}{c}{ Rentang Nilai } \\
\hline Sangat Layak & $>\mathrm{Mi}+1,5 \mathrm{SBi}$ \\
\hline Layak & $\mathrm{Mi}+0,5 \mathrm{SBi}<\mathrm{s.d}<\mathrm{Mi}+1,5 \mathrm{SBi}$ \\
\hline Cukup & $\mathrm{Mi}-0,5 \mathrm{SBi}<\mathrm{s.d}<\mathrm{Mi}+0,5 \mathrm{SBi}$ \\
\hline Kurang Layak & $\mathrm{Mi}-1,5 \mathrm{SBi}<\mathrm{s.d}<\mathrm{Mi}-0,5 \mathrm{SBi}$ \\
\hline $\begin{array}{l}\text { Sangat Kurang } \\
\text { Layak }\end{array}$ & $<\mathrm{Mi}-1,5 \mathrm{SBi}$ \\
\hline
\end{tabular}

Dengan:

Mi $($ Rata-rata ideal $)=1 / 2 \times($ skor maksimal + skor minimal)

SBi (Simpang Baku Ideal) $=1 / 6 \mathrm{x}$ (skor maksimal - skor minimal)

Analisis data responden dilakukan untuk pengguna dalam hal ini siswa yang akan didampingi guru atau orang tua dalam menggunakan video animasi tersebut. Tabel 4 merupakan instrumen kuisioner untuk responden atau user akan menggunakan kuesioner dengan interval skor 1 sampai 7 dan digunakan untuk aspek usability [17][18].

Tabel 4. Instrumen Kuisioner Responden

\begin{tabular}{clc}
\hline No & \multicolumn{1}{c}{ Pertanyaan } & \multicolumn{1}{c}{$\begin{array}{c}\text { Skor } \\
\text { Penilaian }\end{array}$} \\
\hline 1 & $\begin{array}{l}\text { Secara keseluruhan, saya puas } \\
\text { dengan kemudahan dalam } \\
\text { mengakses video animasi hitung } \\
\text { jarimatika }\end{array}$ & 1234567 \\
\hline 2 & $\begin{array}{l}\text { Saya dapat belajar secara efektif } \\
\text { dengan menyimak video ini }\end{array}$ & 1234567 \\
\hline
\end{tabular}




\begin{tabular}{|c|c|c|}
\hline 3 & $\begin{array}{l}\text { Saya dapat belajar berhitung } \\
\text { dengan cepat menggunakan video } \\
\text { ini }\end{array}$ & 1234567 \\
\hline 4 & $\begin{array}{l}\text { Saya dapat belajar efisien dengan } \\
\text { menggunakan video ini }\end{array}$ & 1234567 \\
\hline 5 & $\begin{array}{l}\text { Penyampaian materi dalam video } \\
\text { ini mudah dipahami }\end{array}$ & 1234567 \\
\hline 6 & $\begin{array}{l}\text { Video ini efektif dalam membantu } \\
\text { saya belajar }\end{array}$ & 1234567 \\
\hline 7 & $\begin{array}{l}\text { Tampilan video ini sederhana dan } \\
\text { menarik }\end{array}$ & 1234567 \\
\hline 8 & $\begin{array}{l}\text { Saya suka belajar menggunakan } \\
\text { tampilan semacam ini }\end{array}$ & 1234567 \\
\hline 9 & $\begin{array}{l}\text { Secara keseluruhan, saya puas } \\
\text { belajar dari video ini }\end{array}$ & 1234567 \\
\hline
\end{tabular}

\section{HASIL DAN PEMBAHASAN}

\section{Tahap pra-produksi}

Tahap ini adalah proses yang merupakan pengerjaan dan aktivitas awal sebelum media audio visual di produksi. Jadi semua bahan yang akan digunakan pada proses produksi dan pasca produksi di rinci dan dibuat sketsa awalnya, untuk mempermudah alur pembuatan produk.

\section{a. Menentukan konsep}

Membuat konsep tertentu dalam proses pembuatan animasi pada video pembelajaran jarimatika perlu dibuat sebuah konsep. Pada konsep animasi ini ada seorang mentor atau guru yang memberikan sebuah pelajaran berhitung dengan menggunakan jemari. Konsep ini akan memudahkan penonton untuk dapat terfokus dalam penyampaian pelajaran jarimatika daripada animasi yang tidak memiliki karakter mentor atau guru dalam animasi tersebut.

\section{b. Pembuatan skenario video}

Media yang dibuat merupakan video animasi 2 Dimensi dengan menggunakan teknik motion graphic dan juga penggunaan cycle animation yaitu sebuah animasi yang menggerakan object secara berulang agar object animasi dapat terlihat lebih menarik dari pada menggunakan gambar object yang diam. Pada animasi ini terdapat sebuah karakter yang akan memandu pematerian tentang jarimatika atau perhitungan matematika dengan menggunakan jari jemari. Karakter tersebut akan memberikan sebuah edukasi tentang matematika dasar yaitu tentang penambahan dan pengurangan, pada proses penyampaiannya si karakter memberikan cara menghitung nilai satuan dengan tangan

kanannya dan menghitung nilai puluhan di tangan kirinya, lalu memberikan simulasi kepada penonton tentang proses penambahan dan pengurangan kepada anak - anak dengan contoh objek binatang, benda, dan lain-lain.

\section{c. Storyboard}

Storyboard merupakan acuan dalam pembuatan sebuah media audio visual karena setiap kebutuhan dalam merangkai sequences atau scene sehingga dengan mudah animator untuk menyesuaikan sequences dalam proses editing akhir.

Tabel 5. Storyboard Video Hitung Jarimatika

\begin{tabular}{|c|c|c|}
\hline Scene & Board & Keterangan \\
\hline 1. & & $\begin{array}{l}\text { Bagian awal video } \\
\text { yang memberikan } \\
\text { informasi tentang } \\
\text { judul video animasi. }\end{array}$ \\
\hline 2. & & $\begin{array}{l}\text { Pada bagian ini } \\
\text { karakter } \\
\text { memperkenalkan } \\
\text { diri dan juga } \\
\text { memberikan materi } \\
\text { apa yang akan } \\
\text { disampaikan. }\end{array}$ \\
\hline 3. & & $\begin{array}{l}\text { Pada bagian ini } \\
\text { karakter utama } \\
\text { men-simulasikan } \\
\text { menghitung dengan } \\
\text { menggunakan } \\
\text { simulasi karakter } \\
\text { berupa bangau, } \\
\text { kupu - kupu, dan } \\
\text { kuda laut. }\end{array}$ \\
\hline 4. & & $\begin{array}{l}\text { Pada bagian ini } \\
\text { karakter } \\
\text { mengenalkan cara } \\
\text { menghitung } \\
\text { penjumlahan dan } \\
\text { pengurangan kepada } \\
\text { penonton }\end{array}$ \\
\hline 5. & & $\begin{array}{l}\text { Karakter simulasi } \\
\text { ini menggambarkan } \\
\text { cara menghitung } \\
\text { penjumlahan } \\
\text { dengan menghitung } \\
\text { piala yang } \\
\text { didapatkan oleh } \\
\text { seorang tokoh } \\
\text { karakter. }\end{array}$ \\
\hline 6. & si & $\begin{array}{l}\text { Pada bagian ini } \\
\text { menggambarkan } \\
\text { cara menghitung } \\
\text { pengurangan } \\
\text { dengan cara } \\
\text { mensimulasikan } \\
\text { domba yang kabur }\end{array}$ \\
\hline
\end{tabular}




\begin{tabular}{|c|c|}
\hline & dari kandangnya. \\
\hline 7. & $\begin{array}{l}\text { Pada bagian ini } \\
\text { karakter utama } \\
\text { menjelaskan tentang } \\
\text { cara menghitung } \\
\text { denga jemari } \\
\text { dengan } \\
\text { menggunakan } \\
\text { tangan kanan } \\
\text { sebagai nilai satuan } \\
\text { dan tangan kiri } \\
\text { sebagai nilai } \\
\text { puluhan. }\end{array}$ \\
\hline 8. & $\begin{array}{l}\text { Pada bagian ini } \\
\text { karakter utama } \\
\text { menjelaskan } \\
\text { bagaimana cara } \\
\text { menghitung dengan } \\
\text { contoh angka } 27 \\
\text { yaitu dengan tangan } \\
\text { kanan menghitung } \\
\text { sampai } 7 \text { dan tangan } \\
\text { kiri menghitung } 20 \\
\text { lalu tangan } \\
\text { disilangkan. }\end{array}$ \\
\hline 9. & $\begin{array}{l}\text { Pada bagian ini } \\
\text { karakter utama } \\
\text { sedang menjelaskan } \\
\text { perbedaan nilai } \\
\text { pada tangan kanan } \\
\text { merupakan nilai } \\
\text { satuan dan tangan } \\
\text { kiri merupakan nilai } \\
\text { puluhan. }\end{array}$ \\
\hline 10. & $\begin{array}{l}\text { Pada bagian ini } \\
\text { karakter utama } \\
\text { sedang menjelaskan } \\
\text { cara menghitung } \\
\text { penjumlahan dasar } \\
\text { dengan } \\
\text { menggunakan jari. }\end{array}$ \\
\hline 11. & $\begin{array}{l}\text { Setelah } \\
\text { penjumlahan } \\
\text { berikutnya sedang } \\
\text { mengajarkan } \\
\text { pengurangan } \\
\text { sederhana dengan } \\
\text { menggunakan jari. }\end{array}$ \\
\hline 12. & $\begin{array}{l}\text { Pada bagian ini } \\
\text { karakter utama } \\
\text { sedang } \\
\text { menggunakan jari } \\
\text { bagian kiri yang } \\
\text { digunakan dengan } \\
\text { nilai puluhan. }\end{array}$ \\
\hline 13. & $\begin{array}{l}\text { Karakter utama } \\
\text { menutup video } \\
\text { tentang berlatih } \\
\text { jarimatika. }\end{array}$ \\
\hline
\end{tabular}

\section{Tahap Produksi}

Pada tahap ini, proses pembuatan animasi video dari awal skenario hingga tahap akhir produksi adalah dengan membuat material - material pendukung dalam pembuatan animasi tersebut seperti menggambar karakter, tempat maupun material lainnya. Yang nantinya akan diproses pada tahap pasca produksi.

a. Proses Pembuatan Tokoh Utama

Proses ini merupakan sebuah tahap dimana karakter pemandu atau karakter yang akan memberikan pembelajaran kepada penonton dibuat. Gambar 1 merupakan proses pembuatan karakter pemandu sebagai tokoh utama.

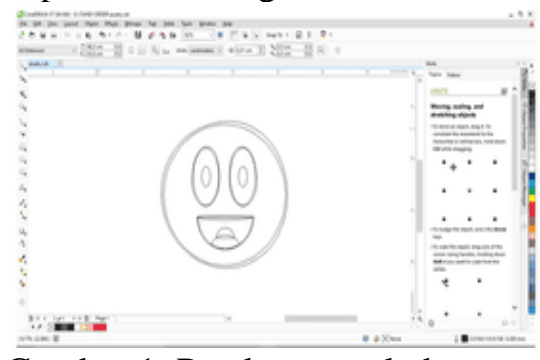

Gambar 1. Pembuatan tokoh utama

\section{b. Proses Pewarnaan}

Adalah proses pewarnaan karakter digunakan sebagai salah satu daya tarik bagi anak-anak yang akan menonton video animasi dengan warna yang lebih kontras sehingga fokus anak - dalam melihat video lebih terarah. Gambar 2 menunjukkan proses pewarnaan tokoh utama.

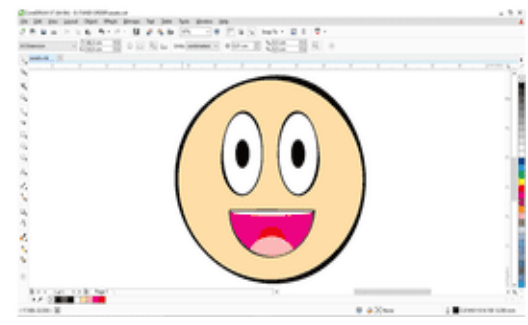

Gambar 2. Proses pewarnaan

c. Pembuatan Objek Tangan

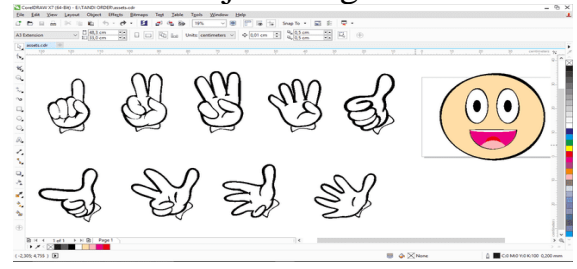

Gambar 3. Pembuatan Objek Tangan

Gambar 3 yaitu pembuatan objek tangan pada karekter berfungsi sebagai sebuah objek yang nantinya akan mengajarkan perhitungan jarimatika dalam video animasi. 
d. Tahap Layer

Adalah tahap layer object yang digunakan sebagai pemisahan antara obyek yang satu dengan yang lainnya. Proses tersebut dapat dilihat pada gambar 4 .

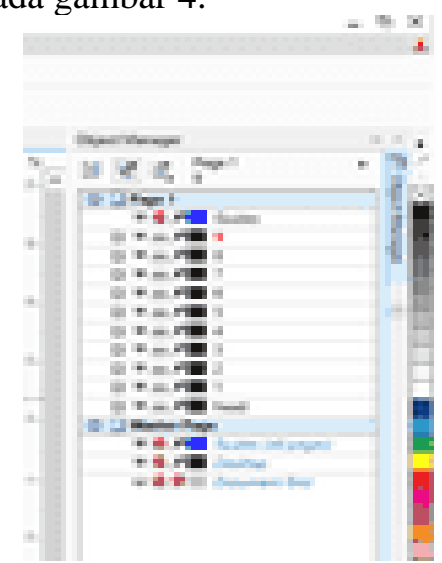

Gambar 4. Tahap layer object

e. Tahap Export Layer

Merupakan tahap meng-export layer dimana hasil ekstensi yang digunakan saat export yaitu menggunakan ekstensi .psd. karena extensi tersebut nantinya akan digunakan pada aplikasi Adobe After effects CS6 pada tahap animasi. Proses tersebut ditunjukkan pada gambar 5.

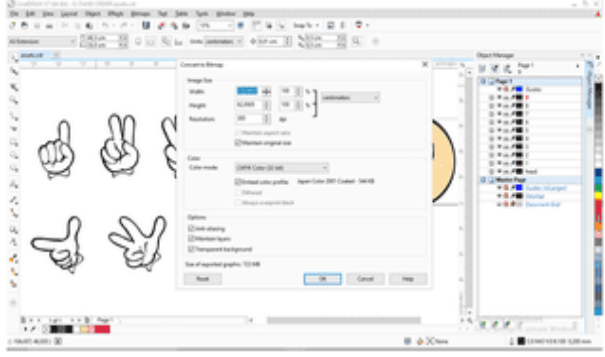

Gambar 5. Tahap Export Layer

\section{f. Tahap Import File}

Proses import file extensi yang berasal dari CorellDraw dengan ekstensi .psd kemudian akan muncul sebah kotak dialog kemudian pada ListBox pilih Composition - Retain Layer size agar object yang dimasukkan sesuai dengan ukuran gambar objek karakter. Proses import dapat dilihat di gambar 6 .

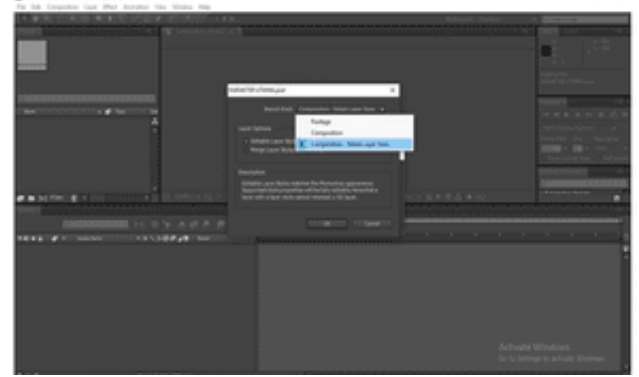

Gambar 6. Tahap import file g. Tahap Penyusunan Gambar Animasi

Merupakan sebuah tahap dimana kita memotong durasi setiap layer menjadi 1 frame kemudian menyusunnya kemudian setelah disusun gunakan efek time remapping fungsinya yaitu untuk mengendalikan durasi. Gambar 7 menunjukkan proses penyusunan gambar animasi.

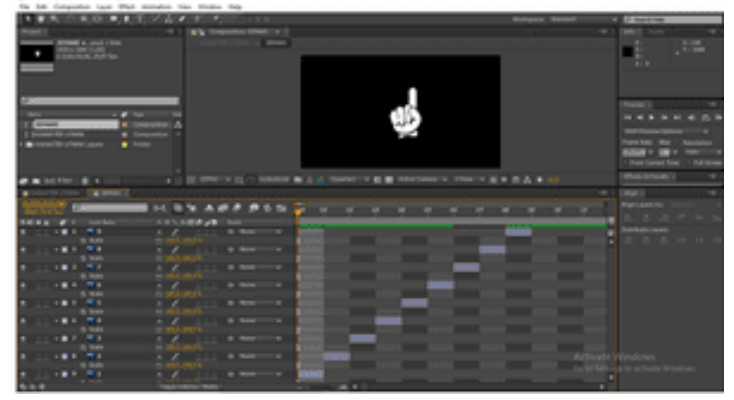

Gambar 7. Penyusunan gambar animasi

h. Proses Penyusunan Sequences

Adalah proses penyusunan sequences yang telah dibuat sebelumnya kemudian diurutkan sesuai dengan storyboard yang ada lalu setelah itu akan dilakukan proses render untuk menyatukan hasil animasi. Proses tersebut ditunjukkan di gambar 8 .

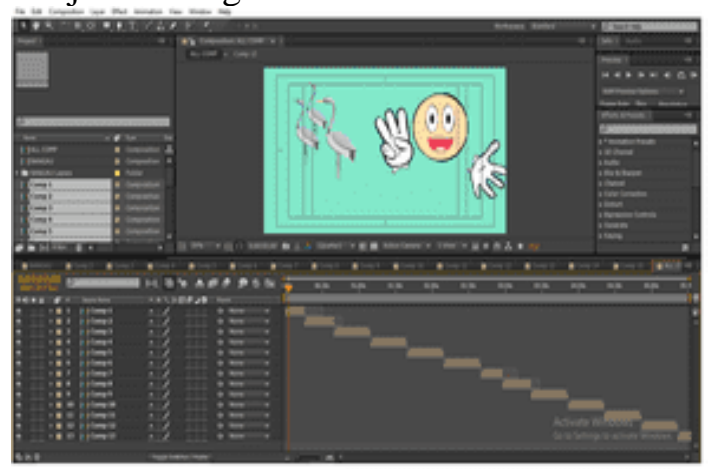

Gambar 8. Proses penyusunan sequences

\section{Tahap Pasca Produksi}

Pasca produksi merupakan tahap penggabungan video, pembuatan tipografi dan melakukan tahap rendering.

a. Penggabungan Video dan rendering

Adalah proses penyatuan antara musik, animasi, dan juga suara dan disesuaikan dengan durasi yang telah dibuat pada tahap pembuatan sequences.

b. Pengujian Alpha Test

Proses ini adalah proses untuk menghasilkan sebuah video utuh dari keseluruhan video menjadi satu kesatuan dan menghasilkan video animasi yang telah utuh storyboard. Alpha Test menguji hasil dengan cara membandingkan 
kebutuhan informasi dengan hasil akhir video. Hasil Pengujian dapat dilihat pada tabel 6.

Tabel 6. Tahap Pengujian Alpha Test

\begin{tabular}{lc}
\hline \multicolumn{1}{c}{ Pengujian } & Hasil \\
\hline $\begin{array}{l}\text { Video pembuka judul } \\
\text { "Belajar Hitung Jarimatika" }\end{array}$ & Sesuai \\
\hline $\begin{array}{l}\text { Menghitung dengan karakter } \\
\text { simulasi. Dalam storyboard } \\
\text { dideskrispikan dengan } \\
\text { karakter yang menunjuk } \\
\text { hewan dan menghitung }\end{array}$ & Sesuai \\
jumlahnya dalam 1 scene \\
dalam pengerjaannya 1 scene \\
tersebut dibagi 3 bagian
\end{tabular}

\begin{tabular}{ll}
\hline $\begin{array}{l}\text { Karkater utama sedang } \\
\text { menjelasakan bagaimana } \\
\text { membuat bilangan angka } \\
\text { dengan jemari }\end{array}$ & Sesuai \\
\hline $\begin{array}{l}\text { Karakter utama mengajarkan } \\
\text { penjumlahan sederhana }\end{array}$ & Sesuai \\
\hline $\begin{array}{l}\text { Karakter utama sedang } \\
\text { mengajarkan pengurangan } \\
\text { sederhana }\end{array}$ & Sesuai \\
\hline $\begin{array}{l}\text { Karakter utama sedang } \\
\text { menjelaskan tentang } \\
\text { penjumlahan nilai puluhan }\end{array}$ & Sesuai \\
\hline \begin{tabular}{l} 
Adegan penutup \\
\hline
\end{tabular} & Sesuai \\
\hline
\end{tabular}

c. Uji validasi dan usability

Pengujian dilakukan oleh ahli media (dosen multimedia), ahli materi (guru TK) dan siswa TK. Tabel 7 merupakan hasil uji validasi ahli media, gambar 8 merupakan hasil uji ahli materi dan tabel 9 merupakan hasil uji usability.

Tabel 7. Hasil Uji Validasi Ahli Media

\begin{tabular}{clccc}
\hline \multicolumn{1}{c}{ Aspek } & \multicolumn{1}{c}{ Indikator } & Nilai & Rata-rata & Kategori \\
\hline Komunikasi Visual & Komunikatif & 9,00 & 4,50 & Sangat Layak \\
& Kreatif dalam gagasan dan ide & 8,00 & 4,00 & Layak \\
& Tampilan sederhana dan menarik & 9,00 & 4,50 & Sangat Layak \\
& Penggunaan visual & 8,00 & 4,00 & Layak \\
& Pemilihan warna & 9,00 & 4,50 & Sangat Layak \\
& Pemilihan jenis huruf & 8,00 & 4,00 & Layak \\
& Kualitas visual dan audio & 9,00 & 4,50 & Sangat Layak \\
\hline
\end{tabular}


Tabel 8. Hasil Uji Validasi Ahli Materi

\begin{tabular}{llccc}
\hline \multicolumn{1}{c}{ Aspek } & \multicolumn{1}{c}{ Indikator } & Nilai & Rata-rata & Kategori \\
\hline Kebenaran Konsep & Kejelasan tujuan pembelajaran & 9,00 & 4,50 & Sangat Layak \\
& Kebenaran materi ditinjau dari aspek keilmuan & 9,00 & 4,50 & Sangat Layak \\
& Penggunaan bahasa & 9,00 & 4,50 & Sangat Layak \\
& Kesesuaian materi & 9,00 & 4,50 & Sangat Layak \\
Penyusunan Materi & Kedalaman materi & 8,00 & 4,00 & Layak \\
& Kontektualitas & 8,00 & 4,00 & Layak \\
& Kelengkapan bahan pendukung materi & 8,00 & 4,00 & Layak \\
& Kemudahan materi untuk dipahami & 9,00 & 4,50 & Sangat Layak \\
Potensi Keterlaksanaan & Alur logika yang jelas & 8,00 & 4,00 & Layak \\
\hline & Rata-rata Keseluruhan & & 4,28 & Layak \\
\hline
\end{tabular}

Berdasarkan hasil uji validasi oleh ahli media dan ahli materi, diperoleh rata-rata secara keseluruhan masing-masing sebesar 4,29 dan 4,28 yang artinya masuk dalam kategori Layak. Sehingga dapat disimpulkan bahwa Video Animasi Menghitung dengan Metode Jarimatika Layak digunakan sebagai media pembelajaran di TK YWKA II Purwokerto.

Tabel 9. Hasil Uji kelayakan Usability

\begin{tabular}{ccc}
\hline Responden & Rata-rata & Kategori \\
\hline R1 & 4,0 & Layak \\
\hline R2 & 6,8 & Sangat Layak \\
\hline R3 & 5,5 & Layak \\
\hline R5 & 4,1 & Layak \\
\hline R6 & 6,6 & Sangat Layak \\
\hline R7 & 5,6 & Sangat Layak \\
\hline R8 & 4,2 & Layak \\
\hline R9 & 5,2 & Layak \\
\hline R10 & 6,5 & Sangat Layak \\
\hline R11 & 5,0 & Layak \\
\hline R12 & 5,4 & Layak \\
\hline R13 & 5,2 & Layak \\
\hline R14 & 5,0 & Layak \\
\hline R15 & 6,0 & Sangat Layak \\
\hline R16 & 5,0 & Layak \\
\hline R17 & 5,8 & Sangat Layak \\
\hline R18 & 4,8 & Layak \\
\hline R19 & 6,8 & Sangat Layak \\
\hline R20 & 4,2 & Layak \\
\hline Rata-rata & $107,2 / 20$ & Sangat Layak \\
\hline Keseluruhan & 5,36 & Layak \\
\hline & & \\
\hline
\end{tabular}

Berdasarkan hasil uji kelayakan usability pada tabel 9, secara keseluruhan rata-ratanya sebesar 5,36 dan termasuk dalam kategori Layak. Sehingga Video Animasi Menghitung dengan Metode Jarimatika telah memenuhi uji aspek kelayakan melalui computer system usability questionnare yang dikembangkan oleh J.R Lewis. Maka video animasi ini dapat digunakan sebagai media pembelajaran bagi siswa di TK YWKA II Purwokerto.

\section{d. Distribusi}

Setelah semua tahapan selesai dikerjakan, langkah berikutnya yaitu dilakukannya pendistribusian atau penyerahan projek video animasi 2D untuk media pembelajaran matematika dasar menggunakan metode jarimatika kepada pihak TK YWKA II Purwokerto. Hasil video dapat dilihat di link: https://www.youtube.com/watch?v=ImE1GbT $\underline{\text { tps }}$

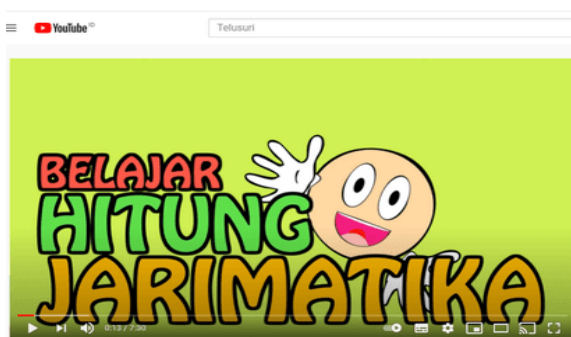

Gambar 9. Tampilan video pada kanal Youtube 


\section{KESIMPULAN}

Berdasarkan hasil dari penelitian dapat disimpulkan bahwa telah berhasil dibuat video animasi 2D dengan judul "Belajar Hitung Jarimatika" sebagai media belajar matematika tentang penjumlahan dan pengurangan menggunakan metode jarimatika untuk TK YWKA II Purwokerto dengan durasi tujuh menit tiga puluh detik dan dari pengujian alpha yang menunjukkan bahwa hasil uji tersebut telah sesuai antara storyboard dengan hasil akhir. Kelayakan video pembelajaran berdasarkan hasil uji validasi ahli media mendapatkan nilai rata-rata keseluruhan 4,29 dan masuk dalam kategori layak. Kelayakan video pembelajaran berdasarkan hasil uji validasi ahli materi menunjukkan nilai rata-rata keseluruhan 4,28 dan juga masuk dalam kategori layak. Video pembelajaran mendapat respon yang baik dalam uji kelayakan usability memperoleh nilai rata-rata keseluruahan 5,36 yang dapat dikategorikan layak sebagai media pembelajaran matematika dasar. Tahap pengembangan dapat dikembangkan lagi dengan metode yang lain selain papper cut dan motion graphic juga pengembangan materi yang disampaikan.

\section{DAFTAR PUSTAKA}

[1] E. Malapata And L. Wijayanigsih, "Meningkatkan Kemampuan Berhitung Anak Usia 4-5 Tahun Melalui Media Lumbung Hitung," J. Obsesi J. Pendidik. Anak Usia Dini, Vol. 3, No. 1, P. 283, Doi: 10.31004/Obsesi.V3i1.183, Apr. 2019.

[2] P. Hartini, "Peningkatan Kemampuan Matematika Anak Melalui Media Permainan Memancing Angka Di Taman Kanak-Kanak Fathimah Bukareh Agam," no. $1,2012$.

[3] G. A. Nur Wulan, D. Priatna, and M. H. Ismail, "Meningkatkan Kemampuan Berhitung Permulaan Anak Usia Dini Melalui Media Permainan Stick Angka," Cakrawala Dini J. Pendidik. Anak Usia Dini, vol. 8, no. 1, doi: 10.17509/cd.v8i1.10551, Mar. 2018.

[4] D. K. Wardhani, "Peran Guru Dalam Menerapkan Pembelajaran Matematika Yang Menyenangkan Bagi Anak Usia Dini," J. PAUD Agapedia, vol. 1, no. 2, p. 7, 2017.
[5] Munir, Multimedia Konsep dan Aplikasi Dalam Pendidikan. Bandung: Alfabeta, 2015.

[6] W. T. Atmojo, M. Irvansyah, and D. Setiyadi, "Metode Multimedia Development Life Cycle Pada Animasi Berhitung Interaktif Sebagai Alat Bantu Belajar Matematika," J. Infor. Sys. For $E d u$, vol 4, no. 1, 2019.

[7] Bernadhed, dkk., "Pengembangan Media Pembelajaran Berbasis Animasi Menggunakan Metode Jarimatika," $J$. Tek. Inf, vol. XIV, no. 1, 2019.

[8] A. S. Afrizal, "Aplikasi Pembelajaran Jarimatika Interaktif Berbasis Multimedia Untuk Pendidikan Sekolah Dasar," $J$. Teknologi, vol. VIII, no. 1, 2018.

[9] A. S. Marleny, Putra, and T. M. Haryani, "Penerapan Metode Jarimatika Berbantuan Adobe Animate Di Kelas III Sekolah Dasar," in S. Nas. Mat. Dan Pendidik. Mat. UNY, 2016.

[10] Y. Arifin, M. Y. Ricky, V. Yesmaya, Digital Multimedia, Cetakan 1. Jakarta: PT WIDIA INOVASI NUSANTARA, 2015.

[11] S. P. Wulandani, Jarimatika. Yayasan Jarimatika Indonesia, 2003.

[12] N. Satria, S. G. Gunanto, and A. Sulistiyono, "Gaa-Mbee: Flower Animasi Dua Dimensi Dengan Teknik Cut Out," J. Animat. Games Stud., vol. 3, no. 2, 2017.

[13] A. Putra, A. D. A. Hermansah, A. Purwanto, "Perancangan Iklan Motion Graphic Jasa Percetakan Alief Production Untuk Meningkatkan Penjualan," $J$. Ilmiah DASI, vol. 14, no. 03, Sep. 2013.

[14] A. Sudijono, Pengantar evaluasi pendidikan, 1st ed, 12. Jakarta: Raja Grafindo Persada (Rajawali Pers), 2011.

[15] S. Andrianita, "Pengembangan Dan Analisis Kualitas Aplikasi Panduan Shalat Jenazah Pada Handphone Berbasis Android," Yogyakarta, 2015.

[16] B. B. Agarwal, S. P. Tayal, and M. Gupta, Software Engineering \& Testing, Computer S. Sudbury, Massachusetts: Jones and Bartlett Publishers, 2010.

[17] J. R. Lewis, "IBM Computer Usability Satisfaction Questionnaires: Psychometric Evaluation and Instructions for Use," Int. J. Hum. Comput. Interact., vol. 7, no. 1, pp. 57-78, 1995. 
[18] J. R. Lewis, "Computer System Usability Questionnaire," Int. J. Hum. Comput. Interact., vol. 7, no. 1, pp. 57-78, 1995. 